\title{
Transformace motivu cesty v podmínkách soudobé globalizace (Sorokin-Topol)
}

\section{Transformation of the Motif of Journey in the Conditions of Contemporary Globalisation (Sorokin-Topol)}

\author{
Michaela Pešková
}

(Plzeň, Česko)

\begin{abstract}
Abstrakt:
Stat' analyzuje a porovnává romány Vladimira Sorokina Manaraga a Jáchyma Topola Citlivý člověk z hlediska ztvárnění motivu cesty. Sleduje, jak se literární motiv cesty transformuje $\mathrm{v}$ procesu postupující globalizace, jehož zachycení je jedním z dominantních námětů obou próz. Syžety románů potvrzují, že mobilita je průvodním jevem globalizace, osudy postav kopírují novodobou migraci národů a kultur. Bytí na cestě je pro hrdiny výhradním způsobem existence, je pro ně bezpř́znakové. Autorka dospívá k závěru, že kompoziční struktura textu navázaná na cestu je pro vyprávění stabilně efektivní a nosná: autoři rozvíjejí motiv cesty jako symbolu životní dráhy, využivají putování hrdinů coby sociální sondu. Dílčí tradiční funkce motivu cesty jsou však výrazně modifikovány. $V$ přerychleném, unifikovaném a „zmenšeném“ světě zaměřeném na trh a konzum ztrácí cesta rozměr duchovní, přestává být způsobem poznání světa i sebe sama, přináší jen mělké výzvy a nevede k zakotvení, respektive $\mathrm{k}$ domovu. I život tak ztrácí jasný směr, mění se v těkání, defilé povrchních podnětů i prezentaci povrchních soudů, a především sled neustálých proměn, což beze sporu odráží existenciální stav současného člověka.
\end{abstract}

\section{Klíčová slova:}

ruská literatura 20. století; česká literatura 2o. století; Vladimir Sorokin; Jáchym Topol; imagologie; globalizace 


\section{Abstract:}

This study analyses and compares Vladimir Sorokin's novel Manaraga and Jáchym Topol's novel A Sensitive Man (Citlivý člověk) in terms of the development of the motif of journey. It observes how the literary motif of journey is being transformed in the process of globalisation, whose depiction is one of the dominant themes of both narratives. Both storylines confirm that mobility is an attendant feature of globalisation. In addition, life stories of literary characters copy a contemporary migration of nations and cultures. Being on the way is an exclusive way of their existence, which is, moreover, asymptomatic for them. The author arrives at the conclusion that the compositional structure related to journey is steadily effective and significant for the narration: the authors develop the motif of journey as a symbol of a way of life. Furthermore, they use wandering of characters as a social probe. However, particular traditional functions of the motif of journey are considerably modified. In a fast-paced, unified and "scaled-down" world aimed at business and consumerism, the way loses its spiritual dimension and ceases to be the way of knowing the world and itself, but brings only superficial challenges and does not lead to moorings, and particularly home. Even life loses a clear direction, changes into volatility, a parade of superficial impulses and a presentation of superficial judgements, and especially to a sequence of constant changes, which undoubtedly reflects an existential state of contemporary man.

\section{Key words:}

2oth-century Russian literature; 2oth-century Czech literature; Vladimir Sorokin; Jáchym Topol; imagology; globalisation

V roce 2017 byly paralelně publikovány romány dvou významných současných spisovatelů, Manaraga Vladimira Sorokina (1955) a Citlivý člověk Jáchyma Topola (1962). Přestože autoři pocházejí $\mathrm{z}$ jiného prostř̌edí a řadí se $\mathrm{k}$ jiným generacím, vykazují texty řadu společných prvků. Především jde o zachycení geopolitických a kulturních posunů $\mathrm{v}$ současném globalizovaném světě. Oba autoři pro tento účel volí efektivní centrální kompoziční princip cesty. Topol provází čtenáře Evropou po roce 2014, Sorokin celým světem blízké budoucnosti. Manaraga i Citlivý člověk přestavují svéráznou variantu roadmovie a částečně i pikareskního románu. Cílem stati je analyzovat, jakým zpo̊sobem se motiv cesty transformuje, zda je v něm možné i nadále rozeznat stabilní, archetypální jádro a oproti němu vydělit dynamickou složku, zda je vzhledem $\mathrm{k}$ aktuálním podmínkám naplněn novým obsahem a co tento obsah vypovídá o soudobém světě a jeho prožívání. Můžeme předeslat, že 
uchopení cesty u Topola je tradičnější. Při komparaci s ním pak vynikne Sorokinův prístup jako výrazněji novátorský, soustředěný na podchycení a anticipaci kardinálních společenských změn.

Hrdinové obou sledovaných románů putují po rozsáhlém prostoru, a to ve zběsilém tempu. U Sorokina cestuje kuchař Géza po klientech z řad novodobé aristokracie, kteří si u něho objednávají ilegální službu book’n-grill, tedy přípravu jídel na hořících originálech knih, v Gézově př́padě ruských. Topolovi hrdinové, rodina složená z táty, mámy a dvou menších synů, se po pobytu v zahraničí, kde vystupovali s estrádními čísly na různých festivalech, navracejí přes Velkou Británii, Madarsko, Slovensko a Novorusko (Donbas) do rodného Posázaví. Tam ovšem v menším měřítku pokračují v potloukání se, respektive protloukání se bez šance na zakotvení a na závěr opět odjiždějí neznámo kam, aby si vůbec zachránili život. Cestování stř̌́dají zřetězená zastavení, jež ale nepřinášejí žádný klid: u Sorokina postupně graduje podivnost zákazníků a jejich vrtochů, u Topola se stupňuje nehostinnost míst, hromadí se pohromy, co na rodinu dopadají, stupňuje se odpudivost popisovaných situací. Cesty mají charakter turné a pracovních „šnưur“. U Sorokina po celém světě: „Po teplém Japonsku jsem najednou na severu. Pak budu zase na jihu. A poté opět na severu. C'est la vie! Dnes mi do uší duje severák, zítra mi vlasy protřepe tropický monzun. "1

Románové světy jednoznačně vykazují rysy globalizovaného světa ${ }^{2}, \mathrm{kdy}_{\text {Sorokin }}$ některé atributy globalizace vzhledem $\mathrm{k}$ umístění děje do budoucnosti ještě domýšlí a hyperbolizuje. Základními aspekty globalizace jsou: mezinárodní obchod, přeshraniční pohyb investic a kapitálu, celosvětová migrace osob a šiření znalostí. Dochází $\mathrm{k}$ proměně prostorové organizace, společenských vztahů a transakcí. V současné vlně globalizace do hry navíc vstupují nová média, informační technologie, které umožňují globální komunikaci s možnostmi nepřetržitého spojení jejích účastníků v nadúzemním prostoru. ${ }^{3}$ Všechny tyto prvky oba spisovatelé, jak uvidíme dále, reflektují.

Globalizace nutí lidi k mobilitě, vysílá je na cestu, její podstatou je šíření, pohyb, migrace. Literární hrdiny daly v obou případech do pohybu vnější okolnosti. Jejich křižování světem je takřka paralelní novodobému stěhování národů. V Manaraze je vyvoláno válkou s islamisty, po níž se přeskupil svět (a podle všeho zaniklo Rusko, což je v kontextu ruské literatury velmi netypické východisko vyprávění), v Citlivém

1 SOROKIN, V.: Manaraga. Praha: Pistorius \& Olšanská, 2017, s. 42.

2 Jáchym Topol komentuje otázku globalizace a Citlivého člověka přímo: „Michael Žantovský mi řekl, že je Citlivý člověk protiglobalizační román, ale mně nepřijde protiglobalizační, jen v žertovné zkratce zachycuje, jak se na globalizaci dívají lidé žijící na venkově kousíček od Prahy, že ji vnímají jen prostřednictvím mekáčů a prodejen Bushman. ŠIMŮNKOVÁ, T.: O nicotě a ponižování. Rozhovor s fáchymem Topolem. [online]. Novinky.cz, 28. června 2017. [Cit. 18. 7. 2019] Dostupné z: https:// www.novinky.cz/kultura/salon/441814-o-nicote-a-ponizovani-rozhovor-s-jachymem-topolem.html.

3 Globalizace. [online]. Wikipedie. Otevřená encyklopedie, 2019. [Cit. 18. 7. 2019] Dostupné z: https:// cs.wikipedia.org/wiki/Globalizace. 
člověku se vpád „barbarských kmenư“ a přerozdělení světa teprve chystá, obyvateli Posázaví jsou však pocit’ovány jako bezprostř̌ední hrozba stejně jako je očekávána nová válka. Krajina má místy postapokalyptické kontury. U Topola je to důraz na spodní prostory, zničené či zanedbané objekty, Sorokin odhaluje „,... dozvuky války: jakési hangáry, všude potrhaný ostnatý drát a zbytky zrezivělé vojenské techniky, které nemá kdo a kam odklidit."

Směr popsaného stěhování národů rámcově odpovídá reálným přesunům z Východu na Západ: Gézovi rodiče přišli do Madarska coby východoslovanští běženci, rodina se vrací domů přes Duklu a objevuje se také postava tátova bratra, který kdysi odešel do SSSR a nyní se pokouší emigrovat zpět. V souladu se soudobými globalizačními trendy je to euroatlantická civilizace, jež v obou prózách představuje epicentrum šiřrení trendů v celosvětově podobného životního stylu. Topol se obává zvyšujícího se vlivu Číny, s čímž se Sorokin vyrovnával jižve Dni opričnika (2008). V Manaraze už Čínu marginalizuje a z její image vybírá jen příznaky „národ šikulü“ a „čínští lékařiı“.

Cestování je v podmínkách „turbulentní reorganizace ekonomického života“5 nezbytné rovněž pro zajištění obživy: Géza musí jezdit za klienty, nikoli oni za ním, rodina pendluje mezi kulturními akcemi, ale za stále se zhoršujících finančních podmínek. Jak známo, globalizací není dosaženo sociální spravedlnosti, nýbrž naopak. Rozpoutaná migrace rozděluje obyvatele na lidi nerovnoměrných kategorií, kdy migranti jsou vždy „podlidmi“: Gézova matka v emigraci již nikdy nemohla vykonávat herecké povolání a musela se živit jako kuchařka ve školní jídelně, lékařská péče nebyla dobrá, protože na běžencích bavorští lékaři šetřili atd.

Sorokin i Topol tematizují globalizační fenomén konzumu, který také spojují s pohybem. Veškeré zboží služby jsou mobilní, vše může být okamžitě dodáno a přesunuto. Globálně cestují i prostitutky: „Překvapení pro tebe... Lien a Tiao, ty dvě okouzlující Vietnamečky, dvojčata. Přesně ty, s niž jsem už třikrát byl štastný -

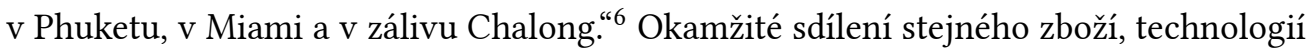
a lidí smazává ostrost geografických hranic mezi zeměmi. Ty na trasách hrdinů obou próz skoro mizí, i fyzické přechody mezi jednotlivými státními útvary jsou jakoby bezešvé.

V globalizovaném světě dochází na jedné straně ke sjednocení, nivelizaci a akulturaci, probíhá „stlačování světa a stále sílící vědomí světa jako jednoho celku“7. Oba autoři zmiňují různé zastřešující mezinárodní organizace, $v$ Manaraze vládne i jednotný Zákon a používá se společný jazyk. Na druhé straně sílí lokální diversifikace: zvyšuje

4 SOROKIN, V.: Manaraga. Praha: Pistorius \& Olšanská, 2017, s. 145.

5 Tamtéž.

6 Tamtéž, s. 164 .

7 Tamtéž. 
se multikulturnost sociálního života ve společnostech, regionech a městech. Hrdinové obou próz se ocitají v nepřetržitém sledu mezikulturních situací. Topol promíchává kultury a zejména jazyky (kontaminace češtiny a ruštiny), lokalita Posázaví však zůstává etnicky homogenní. I sem ale se zprávami zvenčí pronikají obrazy cizinců, například v kázání prezidenta Zemana o Rusech a Číñanech. Zatímco klasicky je právě motiv cesty spojen s poznáním cizího, s viděním nevídaného, v podmínkách globalizace se tento aspekt mění. $\mathrm{K}$,jinému“ není třeba cestovat, skoro každé prostředí je multikulturní. U Sorokina jsou to jak mezinárodně osazená organizace Kuchyně, tak megapole s národnostně vyhraněnými čtvrtěmi, a dokonce i malé vesnice: „Rusové i Somálci, Gruzíni, Tataři, Čečenci, a dokonce i dvě stář́m ohnuté habešské babky... Šest opálených Albánců, kteří ve vesnici žili teprve třetí měsíc... lidé se začali křižovat a v několika jazycích mumlat modlitby... pak se to slilo do jedné mantry. ${ }^{\text {“8 }}$

Romány jsou velmi nasyceny z imagologického hlediska, jde literární texty, v nichž lze prostřednictvím obrazu cizího (heteroimage) a vlastního (autoimage) efektivně zkoumat obraz „jiného“.9 V prŕpadě světoběžníka Gézi máme možnost sledovat přes dvacet národů, tkáň románu lze číst i jako imagologickou mapu světa, i když velmi zploštělou. Se zjednodušením vnímání cizího souvisí právě i odpadnutí funkce cesty coby výpravy do neznáma (neznámo v podstatě neexistuje). Všeobecné sdílení informací, včetně vizuálních, nezakládá potřebu něco objevovat a preferovat osobní zkušenost. Podnětů je navíc príliš mnoho, není čas nad nimi hloubat. Na proniknutí do cizí kultury se rezignuje. Co se týče národů, tyto sou reprezentovány pouze hotovými stereotypy a vykonstruovanými autoimagemi a heteroimagemi, ba dokonce pouhými brendy. ${ }^{10}$ Sorokin u mnoha etnik uvádí pouze jeden atribut, evidentně brend (i kultura je v globalizaci zbožím, z každé se prosadí jen to nejvýraznější): Thajci rovná se masáže a nic jiného, Tibetané rovná se mniši, Japonci suši apod. U Topola jde především o sled stereotypů o Rusku a Rusech ${ }^{11}$, brendem je vodka a Puškin. Islamisty redukuje Sorokin na vrahy s „křivými údy“, obdobně jako Topol: „No, serou se sem ve vlnách, islámci patałý... Navíc nás všechny zabijou.....12

8 Tamtéž, s. 49.

9 ZELENKA, M.: K teórii komparatistickej imagológie (úvodné tézy). In: ZELENKA, M., TKÁČ-ZABÁKOVÁ, L. (eds): Imagológia ako výskum obrazov kultúry. Nitra: Univerzita Konštantina Filozova v Nitre Fakulta stredoeuropských študií Ústav stredoeuropopských jazykov a kultúr, 2018, s. 8.

10 K diferenciaci jednotlivých pojmů viz: PEŠKOVÁ, M. „Avtoimidž “ $i$,geteroimidž naroda v jazykovoj kartine mira $i$ ich metodičeskaja razrabotka. In: DOHNAL, J. (ed.): Opredelenije kartiny mira v russkom jazyke, kul'ture i literature. Brno: Tribun, 2018, s. 151.

11 Více viz: PEŠKOVÁ, M.: Hodnotový obraz Česka a Ruska u fáchyma Topola. In: DOHNAL, J. (ed.): Revitalizace hodnot: umění a literatura. Brno: Ústav slavistiky FF MU, 2018, s. 447-456.

12 TOPOL, J.: Citlivý člověk. Praha: Torst, 2017, s. 270. 
Klasické (mytické) paradigma archetypu cesty je definováno jako schéma odchod z domova - svody a zkoušky - návrat. ${ }^{13}$ Jak se tedy v podmínkách globalizace zachycených ve sledovaných textech mění? Vztah cesty a domova oba autoři problematizují. Románové děje nezachycují opuštění domova, zastihují hrdiny už na cestě. Iniciační rituál osamostatnění se, vydání se do světa na zkušenou proběhl již dávno - ovšem je otázka, zda domov vůbec existoval. Obraz domova je spojen se stabilitou, soustředěním, důvěrností, poklidem, obranou vůči venkovním destrukčním silám. ${ }^{14}$ Některé tyto dojmy si Géza matně pamatuje z dětství v Budapešti, spiše ale nebyly naplněny. Navíc má pocit bezdomoví př́mo geneticky zakódovaný, jelikož jeho rodiče byli uprchlíci. U Topola by vlídným prostorem domova měl být Ladův kraj, v němž ještě žijí přímí předkové rodiny. Po návratu se ale takto dané místo rozhodně neprojevuje, žádná malebnost ani otevřená náruč zde nečekají, „ztracený syn" je vypuzen. Synové prožitek domova neznají vůbec, vyrostli na cestě. Nelze ale tvrdit, že hrdinové jsou doma všude. Permanentní nomádství je vynucené a navozuje stav bezdomoví, u Topola vzhledem $\mathrm{k}$ tomu, $\mathrm{v}$ jakých podmínkách rodina přežívá, už rovnou stav bezdomovectví. Odevšad je vyhánějí, při jejich ilegální, ba kriminální činnosti se musejí většinou rychle spakovat a prchat před pronásledováním. I Géza smí u klientů zůstat jen přesně vymezenou dobu. Cesta jako útěk je tradičním motivem a stvrzuje status hrdinů coby bludných postav z polosvěta přebývajících na okraji společnosti. To u Gézy podtrhuje jeho převládající pohyb ve vzdušném leteckém prostoru: jako padlý anděl náleží této vrstvě nikoho mezi nebem a zemí. Cestování znamená záchranu, je strategií přežití. I Géza si uvědomuje, že jen díky neustálým přesunům je stále naživu.

Ztráta domova a kočování zakládají nejednoznačnou osobní identitu hrdinů. V globalizovaném světě je stále obtížnější definovat sebe sama, přechodová identita a mimikry se také stávají strategií přežití. Géza disponuje šesti cestovními pasy na různá jména a jeho prsty mohou otisky měnit jako rukavice. Rodina naopak pro zastření identity žádné dokumenty nevlastní, ale také se musí maskovat, táta například v jedné epizodě obléká ženské šaty a vydává se za matku.

Bytí na cestě je tedy pro hrdiny obou románů stálý, normální, bezpříznakový stav. Géza zdůrazňuje, že nejdůležitější prostory jsou pro něj letiště, nádraží, hotely, půjčovny aut, tedy tranzitní zóny. K tomu poznamenává: „Samozřejmě to není žádný domov, přinejlepším jen taková předsíň.... ${ }^{15}$ Přestože už devátý rok nemá „... žádnou stálou střechu nad hlavou, jen několik velkých kufrů s oblečením a vybavením“, ${ }^{16}$

13 MELETINSKIJ, J. M.: Poetika mýtu. Praha: Odeon, 1989, s. 323.

14 BACHELARD, G.: Poetika prostoru. Praha: Malvern, 2009

15 SOROKIN, V.: Manaraga. Praha: Pistorius \& Olšanská, 2017, s. 23.

16 Tamtéž 
žádný domov nehledá a ani nebuduje, stav neukotvenosti mu zcela vyhovuje. Přesto román navozením domova končí. Gézovi je poskytnut v útrobách hory Manaraga, kde se jeho cesta uzavírá: „Jen si pobreč, pobreč si, chlapče, hladí mě těma velkýma rukama otcovsky po ramenou. Však jsi doma. ${ }^{17}$ Zpětně lze Gézovo putování vnímat jako způsob dosažení místa klidu, spočinutí, konečného řešení, což je velmi archetypální model. Dalo by se mluvit o dosažení ráje (teplo, světlo, libé vůně a chutě, přivinutí k otcovské osobě, vnitřní klid, ustání bolesti, př́liv energie), kdyby se ovšem nejednalo o klasický antiutopický motiv, násilné podvolení si vzpurnějšího jedince navozením blaženého stavu umělým zásahem do mozku.

Nefunguje ani cesta coby prostředek tužení individuálního charakteru. Hrdinové se nechávají zlákat různými svody (neřesti, prrisvojení si cizího majetku), nijak se jim nesnaží odolávat. $\mathrm{V}$ průběhu a způsobu prožívání cesty přesto nacházíme u obou spisovatelů značný rozdíl. Géza cestuje velmi komfortně, hladce, létá a nechává se vozit. Jen zř́dka zabrousí na periferie - v Manaraze coby nejzapadlejší periferie z neznámých důvodů vystupuje okolí Brna: „Po půldruhé hodině letu jsme přistáli ve vzdálenosti $72,3 \mathrm{~km}$ od Brna. V Brně jsem taky jednou četl. Jenže kde jsme my kuchaři nečetli, hrome!"18 V Citlivém člověku začíná periferie hned kilometr za sjezdem $\mathrm{z}$ dálnice $\mathrm{D} 1$, kde se odehrává větši část děje, typické jsou návštěvy přechodových zón (ukrajinsko-ruská fronta). Cestování rodiny má povahu vysloveně úmorného harcování, jež se projevuje občas smrtelnou únavou a újmami na zdraví. Dopravní prostředky rodinu, až na přelet do Donbasu, príliš neakcelerují, bývají to vraky aut a motorek na hranici životnosti. Tradičnější je varianta Topolova: cesta se prodlužuje, zasekává, objevují se na ní překážky, má nečekané zvraty, odbočky. Přináší ztráty (smrt mámy). Jde o existenciální stav potulky, nicméně natolik diskomfortní, že mu úplně chybí prožitek tulácké volnosti a svobody. I přes tuto zátěž není na pojetí cesty jako cesty za poznáním, dobráním se smyslu nebo nažrení sebe sama ani v Citlivém člověku čas, energie a schází $k$ tomu evidentně i intelekt: Táta jako hybatel rodiny po cestě krade, loupí a ničí a pak musí unikat. Možná probíhá reflexe v rámci toho, že si táta píše deník, ale s jeho obsahem není čtenář seznámen. Máma se sotva vleče a synkové jsou velmi zvláštní, například vůbec nemluví. $O$ jejich duševním světě nevíme nic. Cesta by jim přitom dle klasických modelů měla přinášet zrání (iniciační, výchovný román), ale není tomu tak. Jeden z bratrů se dokonce symbolicky vůbec nevyvíjí, neroste, zůstává batoletem.

Můžeme říci, že Gézovy cesty vykazují určité rysy odysey: překonávání nebezpečí, absolvování zkoušek, vydání se z mnoha sil, poznání pravých přátel a poražení nepřátel. Nicméně všechny tyto motivy jsou velmi změkčeny a zmírněny, nepojí se s heroismem.

17 Tamtéž, s. 163.

18 Tamtéž, s. 136. 
Nebezpečná je například situace, kdy „dřevo“ nehoří, zkoušky se zakládají zejména na sebeovládání před zákazníky, Géza bývá unaven, ale bezprostředně regeneruje, osobní hluboké mezilidské vazby se na cestě nevytvářejí.

Nerealizuje se ani ruská poutnická tradice cesty za pravdou a opravdovostí, navštěvování svatých míst nebo hledání bájných zemí (hora Manaraga skutečně existuje), symbolické sestupy do jiných světů či do podsvětí. Celá Kuchyň je de facto podsvětí a tento prostor je tedy pro hrdinu neutrální.

Gézovy cesty globalizovaným světem tak mají pouze profánní rozměr, jde o jakési povrchní klouzání terénem bez snahy o jeho hlubší pochopení. Géza coby pikaro sice ukazuje na poměry $\mathrm{v}$ různých prostředích, své klienty svádí ke zhřešení a jistým způsobem je obnažuje, sám však zůstává nedotčen a nezměněn, pouze pozoruje či se maximálně podivuje. Další prř́činou, proč se cestě odnímá meditační, kontemplační složka, je rychlost - zrychlení je také jedním z průvodních znaků globalizace. Využívání letecké dopravy jakoby smazává čas a vlastně i prostor a je destrukční pro intenzitu prožívání. Cestu mění v sérii zastávek po nedalekém okolí letišt'. Co se nachází mezi těmito zastávkami, nemůže být z výšky nijak rozlišeno. Cestu v pravém slova smyslu tak hrdina vlastně vủbec neabsolvuje, protože jí neprojde, jen v přískocích vnímá jakési záblesky míst.

Přímý kontakt se světem a jeho skutečné prožití znemožňují Gézovi také všezahrnující digitalizace, nepřetržitý online režim a technologická vylepšení jeho těla. Jakýsi poloorganický ochranně-informační systém chytrých elektronických blech-implantátů vyladěný podle jeho psychosomatiky z něj snímá nutnost se na cestu i nějak chystat, vše má předpřipraveno. Svět pro něj ani nemůže být nijak cizí prostor v archetypálním smyslu neznámý neosvojený, neovládnutý, nebot mu blechy vše dopředu zjistí a hlásí (informace se sítě). Za Gézovy pocity také ve větší míře odpovídají blechy, případně různá chemická povzbuzení, nikoli vnější vlivy. Nelze se přitom spolehnout ani na pravost toho, co hrdina po cestě vidí. Okolní prostředí často jen digitálně bliká, namísto skutečných lidí se zjevují hologramy, prostory stylově čisté (jakoby starý japonský dům, rumunský zámek či usedlost Lva Tolstého) bývají vystavěny uměle, replikovány podle idealizovaných př̀dobrazů. Pout’ světem je putováním klamem: „V naší době si nakonec můžete hrát, na koho chcete. ${ }^{19}$ Topolův svět je tradiční, bez virtuálních prvků, využíván je pouze mobilní telefon, a proto jsou i cestovní zážitky hrdinů syrové, neodfiltrované, autentičtější.

Chybí-li mezní situace a kontemplace, chybí i podklad pro meditace na věčná témata a zážitky, které aktivují hlubinné sféry podvědomí, jak se tomu děje na cestě $\mathrm{v}$ tradičním pojetí. ${ }^{20}$ Géza neprožívá cestu jako existenciální záležitost vrženosti do

19 Tamtéž, s. 48.

20 BUDIL, I. T.: Mýtus, jazyk a kulturní antropologie. Praha: Triton, 2003, s. 153. 
nějakého, at třeba jenom psychicky, extraordinárního stavu, pokud je na cestě pořád. Jeho cesta nemá, kromě honby za penězi a požitky, žádný cíl, osobní ani nadosobní. Géza není žádným nositelem osvěty nebo misionářem (výprava kulturního reka), tedy alespoň zatím. Je důležité, že trajektorie Gézových cest nevytváří lineární trasu, ale sít’ s určitými uzlovými body, mezi nimiž se hrdina nepravidelně pohybuje. $\mathrm{V}$ tomto multisměrovém modelu cesty se zračí chaotická povaha globalizovaného světa. Cesty nevedou odněkud někam, ale odkudkoli kamkoli, cyklí se. Ztrácejí tedy jasnou lineární strukturu kompozičním smyslu: romány mají přes dominantní kostru cesty podobu fragmentární struktury a vzniká syžet „tkáně“, „třiššě“ 21

Románová cesta obvykle symbolizuje model životní dráhy. Pakliže se ani na cestě neodehrává žádný vývoj, je to tak i se životem jako takovým. U Gézy těkavost a povrchnost generuje jakýsi zrychlený model životní dráhy, kdy hrdina ve svých kristových třiceti třech letech plánuje odchod na zasloužený odpočinek za pět let a na čtyřicítku si chystá výměnu všech vnitřních orgánů, plastiku obličeje, nasazení superblech atd. Existenciální rozměr tedy neztrácí jen cesta, ale i život sám: nejde v něm o vývoj, ale o upgrade. U Topola, jak jsme viděli, se vývoj, respektive vývin jedince také neprojevuje. Překotné přesuny ale vedou k opaku: nikoli ve zrychlení životní dráhy (to možná u dospělých $\mathrm{v}$ předčasné miřre jejich opotřebení), ale $\mathrm{k}$ zastavení (chlapci).

Tradiční je rovněž význam cesty jako zasvěcení. Ten se objevuje pouze u Sorokina v závěrečné kontrastní pasáži románu, v nečekané a mimořádné cestě na Severní Ural, na Manaragu. V ději Manaragy se průběžně vyskytují i určité veřejně nepř́ístupné prostory, jako luxusní místa tajných schůzek Kuchyně nebo skryté př́bytky klientů (soukromé hrady nebo ostrovy). Ty ale před Gézou bez problémů otevírají své brány. Teprve vstup do Manaragy je opravdu utajený a je třeba ho fyzicky dobýt. Cesta na Manaragu má oproti jiným váhu výpravy: hrdina plní přidělený velký úkol, má zničit neprrítele, co vyrábí padělky prvotiskủ. Hrozí mu skutečné nebezpečí. Jakmile cesta získá tento archetypální rozměr, mění se i psychické nastavení hrdiny. Jenom zde se objevuje výraznější emoční rozkolísání: pocity nepohodlí, ztráta jistoty, strachu, že tu také může skončit, ale také první transcendentní zážitek, totiž pohled do nekonečného hvězdného nebe. Následuje past a pak zasvěcení do tajných plánů odpadlíků Kuchyně. S aktivizací prastarého významu cesty se aktivizují i jisté tvůrčí síly, v důsledku čehož se prázdnota mění na naplňování vyššího díla, obnovuje se časová perspektiva, navrací se linearita: „Naše oslnivá budoucnost. Do tý vemem všechny! Kuchyň bude vlídná na všechny, Gézo. Všechny budeme mít rádi.“22 Apropos, ve vizi jednotné Kuchyně

21 HODROVÁ, D. a kol.: ... na okraji chaosu... Poetika literárního díla 2o. století. Praha: Torst, 2001, s. 393.

22 SOROKIN, V.: Manaraga. Praha: Pistorius \& Olšanská, 2017, s. 79. 
otevřené všem v podobě mezinárodního řetězce (pro někoho utopické, pro někoho antiutopické) vrcholí románový obraz globalizace.

Archetypální jádro je v motivu cesty v analyzovaných románech stále prrítomno, nebot' cesta je literární (a mytický) konstrukt natolik silný, že není takřka možné, aby v současných literárních textech nasycených v postmoderním duchu odkazy, symboly a mnoha významy nenesl žádné klasické atributy, zvláště u vysoce erudovaných autorů, jakými jsou Vladimir Sorokin a Jáchym Topol. Stabilní tedy zůstává tradiční struktura opuštění domova - zkoušky - návrat, ovšem všechny tyto fáze jsou problematizovány: absence výchozího domova - cesta, která žádné mimořádné situace nepředkládá, nebot' je permanentním rutinním stavem - nemožnost se někam vrátit, případně domov jako zajetí. Literární motiv cesty se při reflexi aktuálního stavu globalizovaného světa výrazně a výmluvně transformuje. $Z$ obrazů cesty dominují ty, které jsou spojeny s nejistotou, tedy bloudění, útěk, mizení. Trajektorie cest je zmatená, roztříštěná, má podobu sítě nikoli linky, nevede $\mathrm{k}$ jasnému cíli, hrdinové po ní těkají. Umocňuje se dojem chaosu, vše se promíchává. V ujednoceném a zrychleném globalizovaném světě, kde jinakost je často jenom umělou hrou na jinakost, se vytrácí smysl cesty jako prostředku poznání světa i sebe sama. Posuny vnější nezpůsobují posuny vnitřní. Zaznamenávat okolní svět lze $\mathrm{v}$ tak intenzivním rozkmitu jen povrchně a často pouze zprostředkovaně, navíc není při celosvětovém sdílení informací ani co poznávat. Absentuje význam cesty jako pouti, chybí jí transcendentní a kontemplativní rozměr. Cestování se redukuje na kořistění a konzum. Svět je, zejména u Sorokina, syntetickým produktem. Stav člověka v těchto souřadnicích je trýznivý: jediná jistota je nejistota a permanentní změna, časovým horizontem je dočasnost, dochází ke ztrátě ukotvující identity, existenciální prožívání se zploštuje. Ke štěstí, smyslu a spočinutí žádná cesta nevede.

\section{Literatura:}

BACHELARD, G.: Poetika prostoru. Praha: Malvern, 2009. ISBN 978-8086702-61-2. BUDIL, I. T.: Mýtus, jazyk a kulturní antropologie. Praha: Triton, 2003. ISBN 80-7254-321-0.

Globalizace. [online]. Wikipedie. Otevřená encyklopedie, 2019. [Cit. 18. 7. 2019] Dostupné z: https://cs.wikipedia.org/wiki/Globalizace.

HODROVÁ, D. a kol.: ... na okraji chaosu... Poetika literárního díla 2o. století. Praha:

Torst, 2001. ISBN 80-7215-140-1.

MELETINSKIJ, J. M.: Poetika mýtu. Praha: Odeon, 1989. 
PEŠKOVÁ, M.: Hodnotový obraz Česka a Ruska u fáchyma Topola. In: DOHNAL, J. (ed.): Revitalizace hodnot: umění a literatura. Brno: Ústav slavistiky FF MU, 2018, s. 447-456. ISBN 978-80-263-0379-4.

PEŠKOVÁ, M. „Avtoimidž $i$ „geteroimidž naroda v jazykovoj kartine mira $i$ ich metodičeskaja razrabotka. In: DOHNAL, J. (ed.): Opredelenije kartiny mira v russkom jazyke, kul'ture i literature. Brno: Tribun, 2018, s. 151-156. ISBN 978-80-263-1402-8.

SOROKIN, V.: Manaraga. Praha: Pistorius \& Olšanská, 2017. ISBN: 978-80-7579-005-7. ŠIMŮNKOVÁ, T.: O nicotě a ponižování. Rozhovor s fáchymem Topolem. [online]. Novinky.cz, 28. června 2017. [Cit. 18. 7. 2019] Dostupné z: https://www.novinky.cz/ kultura/salon/441814-onicote-a-ponizovani-rozhovor-s-jachymem-topolem.html. TOPOL, J.: Citlivý člověk. Praha: Torst, 2017. ISBN 978-80-7215-541-5.

ZELENKA, M.: K teórii komparatistickej imagológie (úvodné tézy). In: ZELENKA, M., TKÁČ-ZABÁKOVÁ,L. (eds): Imagológia ako výskum obrazov kultúry. Nitra: Univerzita Konštantina Filozova v Nitre Fakulta stredoeuropských študií Ústav stredoeuropopských jazykov a kultúr, 2018, s. 7-16. ISBN: 978-80-558-1294-6.

\section{About the author \\ Michaela Pešková \\ University of West Bohemia, Faculty of Education, Department of Russian Language, Pilsen, Czech Republic peskova@krf.zcu.cz}

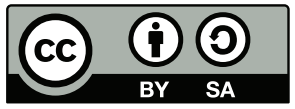

Toto dílo Ize užít v souladu s licenčními podmínkami Creative Commons BY-SA 4.0 International (<https:// creativecommons.org/licenses/by-sa/4.0/legalcode>). Uvedené se nevztahuje na díla či prvky (např. obrazovou či fotografickou dokumentaci), které jsou v díle užity na základě smluvní licence nebo výjimky či omezení príslušných práv. 
